\title{
A Study of Serum Electrolytes in Malnourished Children
}

\author{
Mohd Zakir Mohiuddin Owais ${ }^{1}$, N.L Sridhar ${ }^{2}$ \\ ${ }^{1}$ Assistant professor, Department of Paediatrics, Niloufer Hospital, ${ }^{2}$ Professor, Kamineni Institute of Medical Sciences, Hyderabad.
}

\section{Abstract}

Background: Severe acute malnutrition (SAM) is one of the most common health problems. SAM children are more prone to serious infections that culminate in different co-morbid conditions and result in electrolyte disturbances. Objective: To study the electrolyte profile in severely malnourished children. Subjects and Methods: This was Hospital based cross sectional study. Duration: 1 year from June 2018 to May 2019. Setting: Department of Pediatrics. Participants: 50 Children.Detailed history and physical examination were made. Anthropometric measurements, such as weight and height, were recorded. On admission, electrolytes were performed and children were classified as either hypo / hypernatramic or hypo / hyperkalemic, which depend on the levels of the electrolytes. Result: The Hyponatremia was high with $72 \%$ on the day 1 , and hypernatremia was $6 \%$, on day 3 hyponatremia was $60 \%$ and hypernatremia was $4 \%$ and on day 8 Normal sodium was seen in around $68 \%$ of the children. The mean sodium significantly improved from day 1 to day 8 with a mean of $135.8 \pm 9.9$ on the day 8 th. The Hypokalemia was highest with $38 \%$ on the day 1, Hyperkalemia was seen in $28 \%$ of the patients on day 3 and normal potassium was seen in $80 \%$ of the children on the day 8 th. The mean potassium significantly improved from day 1 to 8 with a mean of $5.5 \pm 1.24$ on the day $8^{\text {th }}$. Conclusion: Most of the children with SAM and electrolyte derangements also had diarrhoea. Therefore determination of the electrolyte profile of all patients with SAM immediately on admission and proceeding days after admission is vital as it helps the clinician to decide on the most appropriate fluids to give to help reduce on the morbidity and mortality associated with life threatening electrolyte derangements.

Keywords: Cord Malnourished, Malnutrition, Electrolytes, Imbalance.

Corresponding Author: Dr. N.L Sridhar, Professor, Kamineni Institute of Medical Sciences, Hyderabad.

Email: drnlsridhar4@gmail.com

Received: March 2020

Accepted: March 2020

\section{Introduction}

Malnutrition, which leads to high child morbidity and mortality, is a major global concern and a complicating variable in other diseases in developing nations. It contributes to 1 million deaths among children annually. ${ }^{[1]}$ There are several abnormalities in malnutrition in body electrolytes, which are more pronounced when combined with diarrheal diseases.

Ionized compounds distributed in blood, skin, and body cells are electrolytes. The mole is either positive or negative and it carries an electrical current to balance $\mathrm{pH}$ and acid in the body. These often promote fluid movement by osmosis between and within cells and help to control the role of the endocrine, neuromuscular and excretive systems.

- Sodium- This helps to balance fluid levels within the body and to enhance the activity of the brain.

- Potassium- is a principal element of cell fluid which helps regulate the role of neuromuscular muscles and osmotic pressure.

- Bicarbonate- It is a negative blood pH-regulating bicarbonate that induces acid base imbalance which increases or decreases in bicarbonate. ${ }^{[1]}$

In malnutrition various abnormalities occur in body electrolytes. Sodium, potassium, bicarbonate and water are the most common electrolyte abnormalities.

In malnutrition with edematous state body water content is increased accompanied by sodium retention that is primarily extra cellular but serum sodium level is reduced in most children with malnutrition masking the sodium overload. Total body potassium is decreased in all malnourished as much as $25 \%$ in overt malnutrition, due to decreased intake and poor muscle mass. Potassium is predominantly intracellular ion needed for maintaining homeostasis integral to normal cellular function but only $2 \%$ of body content is in extra cellular fluid so plasma potassium is a poor indicator of total amount in the body. ${ }^{[3-6]}$

Since both malnutrition and electrolyte imbalance are considered to be risk factors for death among children.7,8,9 This trial thus aims to determine the electrolyte profile in malnourished children with dyselectrolytemia. This would help prevent life-threating situations by early recognition and proper electrolyte change therapy.

\section{Subjects and Methods}

\section{Place Of Study:}

The present study was carried out in the department of pediatrics

\section{Type Of Study:}


This was a cross-sectional observational study

\section{Sample Collection:}

Sample size: 50 malnourished children

Sampling Methods: Consecutive sampling

\section{Inclusion Criteria:}

Children between the ages of 1 year and 5 years who met the WHO criteria for Severe Acute Malnutrition (SAM) were included in the study and 50 normal children

\section{Exclusion Criteria:}

Children less than 1 year or suffering from primary liver disorders or diseases like diabetes mellitus, hypertension, renal disorders etc. were excluded from the study

\section{Statistical Analysis:}

Data were presented in the form of statistical Tables and charts. SPSS software version 20 was used for statistical analysis.

\section{Ethical Approval:}

Approval was taken from the Institutional Ethics Committee prior to commencement of the study.

Detailed history and physical examination were made. Anthropometric measurements, such as weight and height, were recorded. On admission, electrolytes were performed and children were classified as either hypo / hypernatramic or hypo / hyperkalemic, which depend on the levels of the electrolytes.

Blood sample were collected by venipuncture. The blood was allowed to clot and serum was separated by centrifuging the sample.

\section{Results}

\begin{tabular}{|l|l|l|}
\hline Table 1: Children with SAM based on age and gender \\
\hline Variable & No. of patients & Percentage \\
\hline Age in Years & & \\
\hline $1-2$ & 37 & $74 \%$ \\
\hline $2-3$ & 6 & $12 \%$ \\
\hline $3-4$ & 4 & $8 \%$ \\
\hline $4-5$ & 3 & $6 \%$ \\
\hline Gender & & \\
\hline Male & 34 & $68 \%$ \\
\hline Female & 16 & $32 \%$ \\
\hline
\end{tabular}

The Majority of the children with SAM belonged to the age group of 1 to 2 years with $74 \%$ followed by 2 to 3 years of age with $12 \%$ and 3 to 4 years of age with $8 \%$ and the least belonging to the age group of 4 to 5 years with $6 \%$. Male were predominant with $68 \%$ and females were $32 \%$

The Hyponatremia was high with $72 \%$ on the day 1 at the time of admission, and hypernatremia was $6 \%$, on day 3 hyponatremia was $60 \%$ and hypernatremia was $4 \%$ and on day 8 Normal sodium was seen in around $68 \%$ of the children. The mean sodium significantly improved from day
1 to day 8 with a mean of $135.8 \pm 9.9$ on the day $8^{\text {th }}$.

Table 2: Serum electrolyte : Serum sodium in SAM children

\begin{tabular}{|l|l|l|l|}
\hline Variable & Day1 & Day3 & Day 8 \\
\hline $\begin{array}{l}\text { Mean sodium } \\
(\mathrm{mEq} / \mathrm{L}) \pm \mathrm{SD}\end{array}$ & $\begin{array}{l}133.23 \pm 5.45 \\
\text { (range 100- } \\
154)\end{array}$ & $\begin{array}{l}134.62 \pm 5.23 \\
\text { (range 110- } \\
158)\end{array}$ & $\begin{array}{l}135.8 \pm 9.9 \\
\text { (range 126- } \\
173)\end{array}$ \\
\hline Normal sodium & $11(22 \%)$ & $17(34 \%)$ & $34(68 \%)$ \\
\hline $\begin{array}{l}\text { Hyponatremia } \\
(\mathrm{Na}<135 \mathrm{mmol} /)\end{array}$ & $36(72 \%)$ & $31(60 \%)$ & $15(30 \%)$ \\
\hline $\begin{array}{l}\text { Hypernatremia } \\
(\mathrm{Na}>145 \mathrm{mmol} /)\end{array}$ & $3(6 \%)$ & $2(4 \%)$ & $1(2 \%)$ \\
\hline
\end{tabular}

Table 3: Serum electrolytes: Serum Potassium in SAM children

\begin{tabular}{|l|l|l|l|}
\hline Variable & Day1 & Day3 & Day 8 \\
\hline $\begin{array}{l}\text { Mean potassium } \\
(\mathrm{mEq} / \mathrm{L}) \pm \mathrm{SB}\end{array}$ & $\begin{array}{l}4.29 \pm 0.75 \\
\text { (range 1.5-8.7) }\end{array}$ & $\begin{array}{l}5.46 \pm 1.20 \\
\text { (range 2.9-7.7) }\end{array}$ & $\begin{array}{l}5.5 \pm 1.24 \\
\text { (range 3.3-9.2) }\end{array}$ \\
\hline Normal potassium & $15(30 \%)$ & $34(68 \%)$ & $40(80 \%)$ \\
\hline $\begin{array}{l}\text { Hypokalemia } \\
(\mathrm{K}<3.5 \mathrm{mmol} / \mathrm{l})\end{array}$ & $19(38 \%)$ & $2(4 \%)$ & $1(2 \%)$ \\
\hline $\begin{array}{l}\text { Hyperkalemia } \\
(\mathrm{K}>5.5 \mathrm{mmol} / \mathrm{l})\end{array}$ & $16(32 \%)$ & $14(28 \%)$ & $9(18 \%)$ \\
\hline
\end{tabular}

The Hypokalemia was highest with $38 \%$ on the day of admission, Hyperkalemia was seen in $28 \%$ of the patients on day 3 and normal potassium was seen in $80 \%$ of the children on the day 8 th. The mean potassium significantly improved from day 1 to 8 with a mean of $5.5 \pm 1.24$ on the day $8^{\text {th }}$.

\section{Discussion}

We undertook this critical age group study as it coincides with the weaning period and these children are at risk of developing SAM. During weaning, several mothers introduce either the wrong food, with low nutritional value, or insufficiently feed the right food, which is seldom given. Their poor socio-economic status is attributable, which makes them unable to offer the necessary food type for optimum growth.

In this study we have found the incidence of dyselectrolytemia to be very high, mainly involving sodiums, whereas potassium was normal under all conditions of co-morbidity. The most common complications include anorexia, diarrhoea, pneumonia and severe anaemia.

The Majority of the children with SAM belonged to the age group of 1 to 2 years with $74 \%$ followed by 2 to 3 years of age with $12 \%$ and 3 to 4 years of age with $8 \%$ and the least belonging to the age group of 4 to 5years with $6 \%$. Which is much different when compared to study done by Gangaraj S. et al. ${ }^{[10]}$ Male were predominant with $68 \%$ and females were $32 \%$.

The Hyponatremia was high with $72 \%$ on the day 1 at the time of admission, and hypernatremia was $6 \%$, on day 3 hyponatremia was $60 \%$ and hypernatremia was $4 \%$ and on day 8 Normal sodium was seen in around $68 \%$ of the children. The mean sodium significantly improved from day 1 to day 8 with a mean of $135.8 \pm 9.9$ on the day 8 th. In a study by Yasmeen et al, ${ }^{[1]}$ only $3 \%$ had hypernatremia 
which is almost similar to our study.

The Hypokalemia was highest with $38 \%$ on the day of admission, Hyperkalemia was seen in $28 \%$ of the patients on day 3 and normal potassium was seen in $80 \%$ of the children on the day $8^{\text {th }}$. The mean potassium significantly improved from day 1 to 8 with a mean of $5.5 \pm 1.24$ on the day $8^{\text {th }}$.

It was observed from this study that majority of patients with SAM had electrolyte changes between day1 to day 8 which was successfully replenished with the interventions available in the pediatric ward, in terms of fluids and nutritional rehabilitation. This indicates that early detection and intervention for life threatening electrolyte imbalance may help to reduce on morbidity and mortality.

Nevertheless, In malnutrition serum electrolytes do not represent the actual body content but only the circulating concentration, hence high serum potassium masks intracellular potassium deficiency whereas low serum sodium mask sodium overload are critical for immediate therapy in cases of life-threatening disruption. ${ }^{[12]}$

\section{Conclusion}

Electrolyte disturbances may not manifest clinically upon admission, but may become apparent when more electrolytes are lost in stools or vomiting. It is therefore important to assess the electrolyte profile of SAM patients directly after diagnosis and also on the days following admission, as it lets the clinician focus on the most suitable medications to be used to help reduce morbidity and mortality correlated with life-threatening electrolyte disruptions.

\section{References}

1. Mesham AR, Chatterjee M. Wasting away: The crises of malnutrition in India. Washington DC. The World Bank 1999.

2. Post T, Burton R. Clinical physiology of acid base and electrolyte disorders. 5th ed. NewYork. MC Graw- Hill Professional 2001.

3. Jospe N, Forbes G. Fluid and electrolytes clinical aspect. Pediatric Rev 1996;17(11):395-403.

4. Gupte S. The Short Textbook of Pediatrics. Nutritional deficiency state: 8th ed. Dehli; Japee Brothers Medical Publishers 1998;111-4.

5. Mansen JDL, Buchman N, Petifer JM. Protien energy malnutrition 2nd ed. MaclaramSd, Burman D. Newyork Churchill Livingstone 1982;122-3.

6. Subbarao SD, Reha S, Chanrashekhra MK. Hypokalemic Paralysis. Indian Pediatric 1991;425-27.

7. Uysal G, Sokmen A, Vidinlisan S. Clinical risk factors for fatal diarrhea in hospitalized children. Ind J Paedtr 2000;67(5):329-33.

8. Sachdev HP, Kumar S, Singh KK, Satyanarayana L, Puri RK. Risk factor for fatal diarrhoea in hospitalized children in India. J PediatricGastroenterolNutr 1991;12(1):76-81.

9. Mitra AK, Rahma MM, Fuchs GJ. Risk factor and gender differential for death among children hospitalized with diarrhea in Bangladesh. J Health PopulNutr 2000;18(3):151-6.

10. Gangaraj .S, Das. G, Madhulata ,2013. Electrolytes and Blood sugar changes in severely malnourished children and its association with diarrhoea and vomiting. International journal of pharmaceutical science invention. 2(5): 33-36

11. YasmeenMenon, RehanaMajeed, MohammasHanifGhani, Salman Shikh. Serum electrolytes changes in a malnourished child with diarrhea. Pakistan journal of medical science,oct-december 2007 (part I). Volume 23.

12. Doherty CP, Reilly JJ, Peterson WF. Growth failure and malnutrition. In: Walkev VA, edsPediatric Gastro Intestinal Disease 3rd ed. Hamilton Ontario, Decker 2000:12-27.

Copyright: (C) the author(s), 2020. It is an open-access article distributed under the terms of the Creative Commons Attribution License (CC BY 4.0), which permits authors to retain ownership of the copyright for their content, and allow anyone to download, reuse, reprint, modify, distribute and/or copy the content as long as the original authors and source are cited.

How to cite this article: Owais MZM, Sridhar NL. A Study of Serum Electrolytes in Malnourished Children. Asian J.Clin.Pediatr.Neonatol.2020;8(1):41-43.

DOI: dx.doi.org/10.47009/ajcpn.2020.8.1.10

Source of Support: Nil, Conflict of Interest: None declared. 